\title{
Electron microscopical study of myocardial biopsy material in congenital heart block
}

Sir,

Dr. Ludatscher and her colleagues (British Heart fournal (1975), 37, 561) may, I think, have overinterpreted their electron micrographs of myocardial biopsy tissue. The number and appearance of the transverse tubules in their Case 1 (Fig. 2) are not clearly abnormal, particularly as the tissue is overcontracted as so often happens with biopsy material. In animal studies, it is not uncommon to note that the number of transverse tubules seems to vary in different cells and even in different parts of the same cell.

Secondly, the pathological significance of the deep invaginations or deep infoldings of sarcolemma must be open to some doubt. The only illustration of this (Fig. 6) shows invaginations which could well be part of the normal transverse tubular system, as seen when mammalian myocardial cells are sectioned transversely at Z-band level (Simpson, Rayns, and Ledingham, 1973, 1974).

Finally, there is the question of 'focal disruption' of myofibrils. Other authors also have used similar terminology. Alexander (1966, 1967) described myofibrils 'fragmented into short segments' in alcoholic heart disease, while Auger and Chenard (1967) described 'broken myofibrils', and Wellmann (1968) 'short and fragmented myofibrils', in beer drinkers' cardiomyopathy. Burch et al. (1971) described myofibrils in alcoholic mice, that were 'not continuous from one $\mathrm{Z}$ band to the next' so that the 'fragmented unattached myofilaments are incapable of normal contraction'. The illustrations in all these papers (including Fig. 2 of the paper by Ludatscher et al.) show myofibrils cut obliquely so that it is not surprising that the myofibrils pass out of the plane of section. This does not mean that they are disrupted or fragmented in the sense that they come to an end somewhere in the middle of the cell. Such fragmentation is not impossible but so far no convincing evidence for it has been put forward, so far as I am aware. Serial sections or very accurate longitudinal sections down the myofibrils would be required to show this point.
The problem seems partly to be that in some types of myocardial disease the myofibrils have a less parallel orientation than usual. It is not yet clear what this means in terms of attachment of the ends of the myofibrils.

\author{
F. O. Simpson, \\ Wellcome Medical Research Institute, \\ Department of Medicine, \\ University of Otago Medical School, \\ Dunedin, \\ New Zealand.
}

\section{References}

Alexander, C. S. (1966). Idiopathic heart disease. 2. Electron microscopic examination of myocardial biopsy specimens in alcoholic heart disease. American fournal of Medicine, 41, 229.

Alexander, C. S. (1967). Electron microscopic observations in alcoholic heart disease. British Heart fournal, 29, 200.

Auger, C., and Chenard, J. (1967). Quebec beer-drinkers' cardiomyopathy: ultrastructural changes in one case. Canadian Medical Association fournal, 97, 916.

Burch, G. E., Colcolough, H. L., Harb, J. M., and Tsui, C. Y. (1971). The effect of ingestion of ethyl alcohol, wine and beer on the myocardium of mice. American fournal of Cardiology, 27, 522.

Simpson, F. O., Rayns, D. G., and Ledingham, J. M. (1973). The ultrastructure of ventricular and atrial myocardium. In Ultrastructure of the Mammalian Heart, p. 1. Ed. by C. E. Challice and S. Virágh. Academic Press, New York. Simpson, F. O., Rayns, D. G., and Ledingbam, J. M. (1974). Fine structure of mammalian myocardial cells. Advances in Cardiology, 12, 15.

Wellmann, K. F. (1968). Beer drinkers' myocardosis. American fournal of Clinical Pathology, 50, 444.

This letter was shown to Dr. Ludatscher who replies as follows:

I agree that variation in the number of transverse tubules should be considered. However, in numerous thin sections examined from Case 1 the number of $\mathrm{T}$-tubules was impressive in comparison with descriptions of myocardium from patients with 
cardiomyopathy (Van Noorden, Olsen, and Pearse, 1971; Ferrans, Morrow, and Roberts, 1972), and with necropsy material from different heart conditions available in our laboratory.

In Case 2, Dr. Simpson's comments are correct in that the sarcolemmal invaginations could well be part of the transverse tubular system. I opted for 'deep invaginations of the sarcolemma with formation of intracytoplasmic channels', because these channels were not present in the interior of the cell or at the Z-band level though they were of unusual length. As for the focal disruption of myofilaments in areas occupied by clusters of mitochondria, there is no way of proving that disruption had actually oscurred. Nevertheless, myofibrillar disorientation and disruption are known to occur in pathological conditions of the heart (Ferrans et al., 1972).

Ruth Ludatscher, Technion School of Medicine, Haifa, Israel.

\section{References}

Ferrans, V. J., Morrow, A. G., and Roberts, W. C. (1972). Myocardial ultrastructure in idiopathic hypertrophic subaortic stenosis. Circulation, 45, 769.

Van Noorden, S., Olsen, E. G. J., and Pearse, A. G. E. (1971). Hypertrophic obstructive cardiomyopathy, a histological, histochemical and ultrastructural study of biopsy material. Cardiovascular Research, 5, 118. 